\title{
PELATIHAN PENINGKATAN KUALITAS PELAKSANAAN SISTEM AKUNTANSI INSTANSI
}

\author{
Sri Handayati* \\ Djudju Sudjana*
}

\begin{abstract}
The research, conducted from December 2009 through January 2010, aims at evaluating the training model for staff of Education Offices in Riau Islands Province to improve the implementation quality of institution accountancy system (IAS). The method used in this research was survey covering 45 staff members of Education Offices. Data were collected by questionnaire and interview and analyzed quantitatively and qualitatively. Data analysis concludes that the existing training model suffers from weakness in its system, management, and evaluation. Further, it is recommended an alternative training model to be developed on the basis of staff's need in improving knowledge, skills, and attitude on the SAI implementation.
\end{abstract}

Keywords: training model, institution accountancy system, manajemen, evaluation

\begin{abstract}
Abstrak
Penelitian yang diselenggarakan mulai Desember 2009 sampai Januari 2010 ini bertujuan untuk menilai Model Pelatihan Pegawai Dinas Pendidikan di Provinsi Kepulauan Riau untuk pelaksanaan Sistem Akuntansi Instansi (SAI). Lingkup penilaian mencakup perencanaan, pelaksanaan, hasil,dan evaluasi, sehingga dapat diketahui keunggulan dan kelemahannya. Metode penelitian yang digunakan adalah survey terhadap 45 orang pegawai sebagai responden. Data diperoleh melalui kuesioner yang dikuatkan dengan wawancara dan dianalisis secara kuantitatif dan kualitatif. Hasil analisis menunjukkan, model pelatihan yang dipakai memiliki berbagai kelemahan dalam sistem, manajemen, dan evaluasi. Oleh karena itu disarankan agar dirancang dan dikembangkan model pelatihan alternatif yang seuai dengan kebutuhan pegawai dalam meningkatkan pengetahuan, keterampilan, dan sikap pegawai untuk melaksanakan SAI.
\end{abstract}

Kata-kata kunci: model pelatihan, sistem akuntansi instansi, manajemen, evaluasi

\section{PENDAHULUAN}

Kemampuan pegawai dalam pengelolaan keuangan secara tepat dan efesien ditinjau dari sistem dan prosedur pembukuan dan pelaporan keuangan sesuai Sistem Akuntansi Instansi (SAI) tergantung pada sejauh mana pengetahuan yang diperolehnya. Pelatihan sangat berperan penting dalam upaya meningkatkan kemampuan pegawai. Pelatihan adalah proses pendidikan jangka pendek yang menggunakan prosedur yang sistematis dan terorganisasi yang dapat diikuti oleh pegawai untuk mengembangkan kemampuannya dalam bekerja. Schuler (1987: 113) menyatakan "Training and development is defined as the human resource practice whose focused on identifying assessing and through planned learning to help the development the key competencies which enable

\footnotetext{
* Mahasiswa Sekolah Pascasarjana UPI, Bandung
}

2) Dosen Sekolah Pascasarjana, UPI, Bandung people to perform current or future job".

Permasalahan kemampuan pegawai Kantor Dinas Pendidikan terjadi di lapangan dalam hal pengelolan keuangan, khususnya wilayah Provinsi Kepulauan Riau, perlu dicari pemecahannya. Hasil pemeriksaan Badan Pemeriksa Keuangan Republik Indonesia semester I tahun 2006 atas laporan keuangan Provinsi Kepulauan Riau Tahun anggaran 2005 di Tanjung Pinang terdapat masalah-masalah material yang ditemukan berkaitan dengan sistem akuntansi instansi yang digunakan yaitu: (1) pelaksanaan pembukuan dan penyusunan laporan keuangan secara umum tidak mengikuti prinsip-prinsip akuntansi yang berlaku diantaranya Buku Kas Umum Bendaharawan Umum Daerah, Jurnal, Buku Besar maupun Buku Besar Pembantu tidak diselenggarakan dan (2) pengendalian intern atas penerimaan dan pengeluaran kas lemah 
antara lain ditunjukkan dari rekonsiliasi yang tidak pernah dilakukan perbulan selama tahun 2005. Berdasarkan pemeriksaan terhadap Laporan Keuangan Provinsi Kepulauan Riau Tahun Anggaran 2005, BPKRI berpendapat bahwa Laporan Keuangan Provinsi Kepulauan Riau Tahun Anggaran 2005 tidak disajikan secara wajar untuk semua hal yang material sesuai dengan Prinsip Akuntansi yang ditetapkan di dalam Standar Akuntansi Pemerintahan dan berbagai peraturan perundangan yang berlaku (BPK, 2006: 2).

Pemeriksaan oleh Badan Pemeriksa Keuangan Republik Indonesia (BPK RI) terhadap Neraca Pemerintah Daerah Provinsi Kepulauan Riau per 31 Desember 2007, tentang Laporan Realisasi Anggaran, Laporan Arus Kas dan Catatan atas Laporan Keuangan untuk tahun yang berakhir pada tanggal tersebut telah dilakukan. Laporan keuangan dimaksud merupakan tanggung jawab Pemerintah Daerah Provinsi Kepulauan Riau. BPK RI menemukan adanya ketidakpatuhan kepada ketentuan peraturan perundangan-undangan, kecurangan, serta ketidakpatuhan yang material. Temuan telah dimuat oleh BPK RI dalam Laporan Keuangan Hasil Pemeriksaan tertanggal 21 Juli 2008 kepada Pemerintah Daerah Provinsi Kepulauan Riau. Hasil pemeriksaan yang meninjau tentang pencatatan kekayaan daerah berupa aset tetap yang diserahterimakan secara terpisah sehingga pencatatan aset tersebut oleh Pemerintah Provinsi Kepulauan Riau belum sepenuhnya memenuhi karakteristik aset dalam Standar Akuntansi Pemerintahan (BPK, 2008: iv).

Upaya peningkatan kinerja pegawai dalam pengelolaan keuangan telah banyak dilakukan. Upaya ini dilakukan oleh berbagai lembaga keuangan pemerintah pada berbagai departemen maupun berbagai wilayah pemerintahan daerah melalui pelatihan pegawai, khususnya bagi pegawai Kantor Dinas Pendidikan. Pelatihan yang diselenggarakan membutuhkan waktu, sumberdaya, dan dana yang besar. Umumnya pelatihan pegawai yang dilangsungkan berupa pelatihan klasikal yang meninggalkan sementara tempat kerja dan pekerjaannya.

Model pelatihan alternatif bagi pegawai dalam pelaksanaan sistem akuntansi instansi yang memiliki potensi dalam upaya peningkatan pengetahuan, keterampilan, dan sikap pegawai sangat dibutuhkan. Makalah ini menyajikan gambaran kemampuan pegawai kantor Dinas Pendidikan dalam pelaksanaan Sistem Akuntansi Instansi setelah mengikuti pelatihan dengan menerapkan model pelatihan yang telah berlangsung saat ini. Gambaran kemampuan pegawai disertai dengan bagaimana sistem, manajemen, pelaksanaan, dan hasil pelatihan pegawai dalam pelaksanaan SAI yang telah diikuti dapat digunakan sebagai pertimbangan dalam merancang model pelatihan alternatif yang dibutuhkan.

\section{KAJIAN TEORETIS}

Pelatihan menurut Sumantri (2001: 2) adalah proses pendidikan jangka pendek yang menggunakan prosedur yang sistematis dan terorganisasi. Pelatihan merupakan suatu kegiatan yang dirancang untuk mengembangkan sumber daya manusia melalui rangkaian kegiatan identifikasi, pengkajian serta proses belajar yang terencana. Hal ini dilakukan melalui upaya untuk membantu mengembangkan kemampuankemampuan utama yang diperlukan agar dapat melaksanakan pekerjaan, baik sekarang maupun pada masa yang akan datang (Laird, 1985: 11; Schuler, 1987: 113). Pelatihan dapat dilakukan melalui penggunaan model atau tahapan model yang sesuai dalam rangka mencapai tujuan.

Model pelatihan merupakan kerangka konseptual yang digunakan sebagai pedoman deskrispsi untuk membantu visualisasi dalam menggambarkan secara sistematis proses warga belajar untuk memperoleh kecakapan khusus agar dapat mencapai kinerja dalam pelaksanaan tugas tertentu melalui pengembangan berfikir, sikap, pengetahuan, kecakapan dan kemampuan. Model-model pelatihan yang ada diantaranya adalah Model Critical Event (Nedler 1982: 12) dan model siklus pelatihan lima tahap (Goad, 1982: 11). Model pelatihan Continuous Loop Training Development and Implementation Model (Mayo \& Du Bois, 1987:3); dan model proses pelatihan enam tahap "six stages of the training process" dalam (Friedman dan Yarbrough, 1985: 4). Model pelatihan yang digunakan dalam perencanaan, pelaksanaan, dan evaluasi proses pelatihan terkait dengan konteks warga belajar.

Pelatihan yang dilakukan di manapun dan kapanpun adalah merupakan pembelajaran yang dilakukan pendidik (pelatih, widyaiswara) terhadap peserta didik (peserta latihan) di tempat atau panti pelatihan yang tersedia atau disediakan untuk itu seperti di tempat kerja, kantor, atau sekolah (Sudjana, 2005: 7). Konteks tersebut menunjukkan bahwa pelatihan di tempat kerja adalah pelatihan dengan penyusunan 
rangkaian pembelajarannya dilangsungkan di tempat belajar. Susan \& John (2006: 55), mengungkapkan bahwa pendekatan pembelajaran di tempat kerja (workplace learning) dalam tataran organisasi dapat dipertimbangkan sebagai bentuk pembelajaran yang efektif di dalam pelatihan di tempat kerja. Warga belajar yang terlibat dalam menentukan tujuan belajar, diyakini memiliki motivasi dan percaya diri yang kuat dalam melakukan proses belajar. Pelatihan di tempat kerja dapat mengambil peran dalam meningkatkan kinerja pegawai dalam pengelolaan keuangan daerah.

Pengelolaan keuangan daerah dilakukan dengan menggunakan Sistem Akuntansi Instansi yang berlaku bagi setiap instansi pemerintah tanpa terkecuali bagi Dinas Pendidikan di provinsi, kabupaten, maupun kota. Asas pengelolaan keuangan daerah secara umum ditetapkan dalam Peraturan Pemerintah Nomor 58 Tahun 2005. Peraturan Pemerintah tersebut menyatakan bahwa keuangan daerah dikelola secara tertib, taat pada peraturan perundang-undangan, efisien, ekonomis, efektif, transparan, dan bertanggungjawab dengan memperhatikan asas keadilan, kepatutan, dan manfaat untuk masyarakat. Pengelolaan keuangan daerah dilaksanakan dalam suatu sistem yang terintegrasi terwujud dalam Anggaran Pendapadan dan Belanja Daerah (APBD) yang setiap tahun ditetapkan dengan peraturan daerah (Tanjung, 2008: 18). Peraturan Mendiknas Nomor: 16 Tahun 2008 dalam ketentuan umum pasal 1, menyatakan bahwa: Sistem Akuntansi Instansi yang selanjutnya disebut SAI adalah serangkaian manual mulai dari pengumpulan data, pencatatan, pengikhtisaran sampai dengan pelaporan posisi keuangan dan operasi keuangan pada kantor/Satker (Depdiknas, 2008: 1).

\section{METODOLOGI PENELITIAN}

Penelitian mengunakan metode kualitatif dengan teknik survei. Penelitian ini dilakukan bulan Desember 2009 sampai Januari 2010 pada enam Kantor Dinas Pendidikan Kabupaten/Kota yang ada di Provinsi Kepulauan Riau dengan jumlah responden 45 orang. Responden dikelompokkan menjadi dua kelompok, yaitu: (1) kelompok masa kerja 0 sampai 5 tahun sebanyak 17 orang, dan (2) kelompok masa kerja di atas 5 tahun sebanyak 28 orang. Pengelompokan tersebut dilakukan berdasarkan pengalaman kerja. Pegawai dengan masa kerja 0 sampai 5 tahun belum berpengalaman dalam bekerja dan hanya mengikuti pelatihan SAI sebanyak 1 atau 2 kali, sedangkan pegawai dengan masa kerja di atas 5 tahun telah berpengalaman dalam bertugas dan telah mengikuti pelatihan SAI lebih dari 2 kali.

Tanggapan responden sebagai pegawai yang pernah mengikuti pelatihan pelaksanaan sistem keuangan atau SAI tentang perencanaan proses pelatihan, pelaksanaan pelatihan, hasil pelatihan, dan kelemahan model pelatihan. Tanggapan responden dihitung persentasenya dan dikelompokkan dalam kriteria baik, cukup, dan kurang. Kriteria baik (B) diberikan bila 76 - 100\% indikator terpenuhi. Kriteria tentang komponen pelatihan yang pernah diikuti pegawai dinyatakan Cukup (C) bila indikator yang terpenuhi sebanyak $56 \%$ - $<75 \%$, dan kriteria Kurang (K) bila hanya $0 \%$ - < 55\% indikator yang ada terpenuhi menurut respon dari pegawai.

\section{Hasil Survei}

Hasil survey mengungkap kualitas pelatihan SAI yang pernah diikuti oleh pegawai kantor dinas pendidikan. Kualitas pelatihan keuangan atau SAI yang baik dipresentasikan dalam 10 komponen dan 22 indikator: komponen sistem yang digunakan; manajemen yang diterapkan; kesesuaian penggunaan metode pelatihan; ketepatan penggunaan media dalam pelatihan; penyajian materi pelatihan; pengetahuan yang di serap oleh peserta pelatihan; keterampilan yang diperoleh peserta pelatihan; perubahan peningkatan sikap peserta pelatihan; adanya keterkaitan analisis kebutuhan, pelaksanaan program, dan evaluasi; dan adanya keterkaitan kebijakan, materi pelatihan, dan kebutuhan kerja. Persentase respon pegawai tentang pelatihan yang pernah diikuti dalam untuk keseluruhan komponen pelatihan berdasarkan masa kerja dan kriteria respon diperlihatkan pada Gambar 1. Responden dikelompokkan dalam kriteria baik, cukup, dan kurang untuk pegawai masa kerja 0 sampai 5 tahun dan di atas 5 tahun.

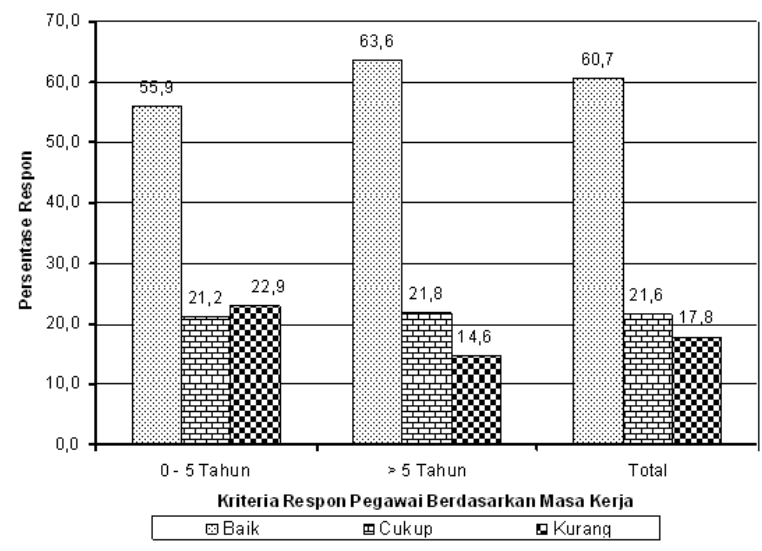

Gambar 1. Grafik persentase respon pegawai terhadap pelatihan yang pernah diikuti dalam masa kerja 0-5 tahun dan $>5$ tahun dalam tiga kriteria 
Pegawai dengan masa kerja di bawah lima tahun sebagian besar $(55,9 \%)$ menyatakan pelatihan SAl yang pernah mereka ikuti berkualitas baik, namun masih cukup besar $(44,1 \%)$ yang menyatakan bahwa pelatihan SAl yang mereka ikuti berkualitas cukup dan kurang dalam hal perencanaan proses pelatihan, pelaksanaan pelatihan, hasil pelatihan, dan kelemahan model pelatihan. Pegawai dengan masa kerja di atas lima tahun sebagian besar $(63,6 \%)$ menyatakan pelatihan SAI yang pernah mereka ikuti berkualitas baik, namun juga masih cukup besar $(36,4 \%)$ yang menyatakan bahwa pelatihan SAI yang mereka ikuti cukup dan kurang. Pegawai Dinas Pendidikan yang pernah mengikuti pelatihan SAI sebanyak 45 orang secara keseluruhan sebanyak $60,7 \%$ menyatakan bahwa perencanaan proses pelatihan, pelaksanaan pelatihan, hasil pelatihan, dan kelemahan model pelatihan baik dan $39,4 \%$ menyatakan hanya cukup dan kurang baik. Hasil ini menunjukkan bahwa perencanaan proses pelatihan, pelaksanaan pelatihan, hasil pelatihan, dan kelemahan model pelatihan SAI yang pernah diikuti pegawai belum mencapai hasil yang maksimal dan perlu diperbaiki.

Persentase respon pegawai terhadap pelatihan yang pernah diikuti dalam berbagai komponen pelatihan berdasarkan kriteria dan masa kerja diperlihatkan pada Gambar 2. Responden dikelompokkan dalam kriteria baik, cukup, dan kurang untuk pegawai masa kerja 0 sampai 5 tahun dan di atas 5 tahun.

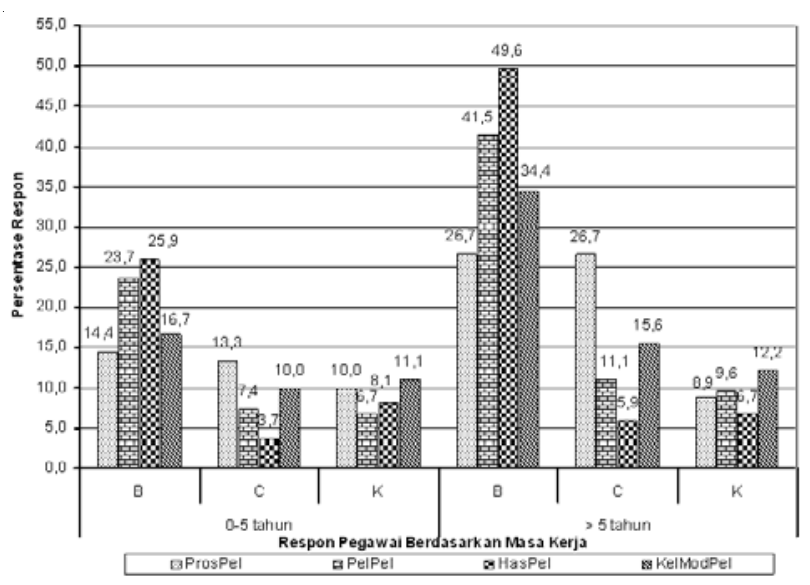

Gambar 2. Grafik persentase respon pegawai masa kerja 0-5 tahun dan $>5$ tahun, terhadap pelatihan yang pernah diikuti dalam tiga kriteria untuk komponen proses pelatihan (Prospel); pelaksanaan pelatihan (PelPel); hasil pelatihan (Haspel); dan kelemahan model pelatihan (KelModPel).

Deskripsi respon pegawai terhadap pelatihan SAI yang pernah diikuti komponen Proses pelatihan (Prospel), Pelaksanaan Pelatihan (PelPel), hasil pelatihan (Haspel), dan Kelemahan Model Pelatihan (KelModPel) seperti berikut ini:

\section{Perencanaan Proses Pelatihan}

Komponen sistem dan manajemen pelatihan yang merupakan tahapan perencanaan pelatihan terdiri dari dua indikator: (1) pelatihan yang dikatakan baik, berjenjang sesuai dengan jabatan dan terkait dengan promosi jabatan mapun gaji dan (2) manajemen pelatihan yang baik, bila direncanakan dengan baik dan pelaksanaan pelatihan dievaluasi atau ditindak lanjuti dengan baik saat setelah pelatihan di lembaga pelatihan maupun disaat melaksanakan tugas.

Persentase tanggapan responden terhadap pelatihan terkait dengan perencanaan proses pelatihan SAl yang pernah diikuti diperlihatkan pada Gambar 2. Pegawai dengan masa kerja di bawah lima tahun hanya sebagian kecil $(38,2 \%)$ menyatakan pelatihan SAI yang pernah mereka ikuti berkualitas baik, namun masih cukup besar $(61,8 \%)$ yang menyatakan bahwa pelatihan SAl yang mereka ikuti berkualitas cukup dan kurang. Pegawai dengan masa kerja di atas lima tahun juga sebagian kecil $(42,9 \%)$ menyatakan pelatihan SAl yang pernah mereka ikuti berkualitas baik, namun masih cukup besar $(57,1 \%)$ yang menyatakan bahwa pelatihan SAl yang pernah mereka ikuti memiliki kualitas cukup dan kurang.

Pegawai Dinas Pendidikan yang pernah mengikuti pelatihan SAl sebanyak 45 orang secara keseluruhan hanya sebanyak $41,1 \%$ menyatakan bahwa perencanaan proses pelatihan yang diikuti baik dan $58,9 \%$ menyatakan cukup dan kurang. Pegawai yang pernah mengikuti pelatihan menyatakan bahwa pelatihan yang diikutinya berjenjang sesuai dengan jabatan dan kurang terkait dengan promosi jabatan mapun gaji. Manajemen pelatihan yang direncanakan terlaksana dengan baik dan pelaksanaan pelatihan dievaluasi atau ditindak lanjuti dengan baik saat setelah pelatihan di lembaga pelatihan, namun evaluasi ini tidak dilakukan saat melaksanakan tugas. Hasil ini menunjukkan bahwa perencanaan proses pelatihan SAI yang diikuti pegawai masih belum sesuai dengan yang diharapkan dan sangat membutuhkan perbaikan. Perbaikan dimaksud dalam hal sistem dan manajemen pelatihan.

\section{Pelaksanaan Proses Pelatihan}

Komponen penggunaan metode, media, dan penyajian materi pelatihan merupakan tiga komponen pelaksanaan pelatihan yang telah diikuti pegawai. Pelaksanaan pelatihan dengan tiga komponen tersebut masing-masing terdiri dari dua indikator. Indikator komponen penggunaan metode pelatihan yaitu: (1) kesesuaian dengan materi pelatihan dan (2) metode 
tersebut mendukung penguasaan materi pelatihan. Indikator komponen penggunaan media dalam pelatihan yaitu: (1) kemampuan menggunakan media tersebut dan (2) kemampuan media yang digunakan dalam memperjelas penyajian materi pelatihan. Indikator komponen penyajian materi pelatihan yaitu: (1) kemampuan menyajikan teori penambah pengetahuan, terkait, dan mendukung kegiatan praktik dan (2) kemampuan melakukan praktik untuk meningkatkan keterampilan serta sikap pegawai.

Persentase tanggapan responden terhadap pelatihan terkait dengan pelaksanaan proses pelatihan SAl yang pernah diikuti seperti pada Gambar 2. Pegawai dengan masa kerja di bawah lima tahun dengan jumlah cukup besar $(62,7 \%)$ menyatakan pelaksanaan pelatihan SAI yang pernah mereka ikuti berkualitas baik, namun masih terdapat $(37,2 \%)$ yang menyatakan bahwa pelaksanaan pelatihan SAI yang mereka ikuti hanya berkualitas cukup dan kurang. Pegawai dengan masa kerja di atas lima tahun juga sebagian besar $(66,7 \%)$ menyatakan pelatihan SAI yang pernah mereka ikuti berkualitas baik, namun masih terdapat sebagian kecil $(34,4 \%)$ yang menyatakan bahwa pelatihan SAI yang pernah mereka ikuti hanya memiliki kualitas cukup dan kurang.

Pegawai Dinas Pendidikan yang pernah mengikuti pelatihan SAI sebanyak 45 orang secara keseluruhan sebanyak 65,2\% menyatakan bahwa pelaksanaan pelatihan yang diikuti kualitas baik dan hanya $34,8 \%$ menyatakan kualitas pelatihan cukup dan kurang. Hasil wawancara mengungkapkan bahwa penggunaan metode pada beberapa penyajian materi pelatihan seperti penyusunan laporan keuangan kurang sesuai dengan materi pelatihan sehingga metode tersebut tidak mendukung penguasaan materi pelatihan. Metode yang semestinya tepat untuk digunakan adalah studi kasus yang dapat menghadapkan pegawai pada permasalahan yang sebenarnya dihadapi dan mencari solusi masalah tersebut. Penggunaan media dalam pelatihan oleh pelatih pada umumnya menurut pegawai peserta pelatihan menyatakan bahwa pelatih mampu menggunakan media dalam pelatihan dan media yang digunakan dapat memperjelas penyajian materi pelatihan. Penyajian materi teori dalam pelatihan oleh pelatih menambah pengetahuan, terkait dan mendukung kegiatan praktik, namun praktik yang dilakukan kurang meningkatkan keterampilan serta sikap pegawai.

Hasil ini menunjukkan bahwa pelaksanaan pelatihan SAI yang diikuti pegawai masih perlu ditingkatkan hingga memungkinkan hasil pelatihan yang maksimal. Peningkatan kualitas pelaksanaan pelatihan
SAI dimaksud dapat dilakukan dalam hal pengggunaan metode pelatihan yang tepat dan sesuai dengan kebutuhan peserta pelatihan. Pelatihan SAI juga harus diupayakan agar lebih meningkatkan keterampilan pegawai dalam pelaksanaan SAI dan sikap pegawai dalam melaksanakan tugas.

\section{Hasil Pelatihan}

Komponen pengetahuan, keterampilan, dan sikap merupakan tiga komponen hasil pelatihan yang masing-masing terdiri atas dua indikator. Indikator penguasaan pengetahuan yaitu: (1) adanya peningkatan pengetahuan dan (2) adanya peningkatan pengetahuan tersebut mendukung aplikasi dalam kerja. Indikator penguasaan keterampilan yaitu: (1) adanya peningkatan keterampilan dan (2) adanya peningkatan keterampilan tersebut bermanfaat dalam penyelesaian tugas setelah mengikuti pelatihan. Indikator perubahan sikap yaitu: (1) adanya peningkatan ketelitian dan (2) adanya peningkatan disiplin dalam kerja.

Persentase tanggapan responden terhadap pelatihan terkait dengan hasil pelatihan SAI yang pernah diikuti seperti pada Gambar 2. Pegawai dengan masa kerja di bawah lima tahun dengan jumlah cukup besar $(68,6 \%)$ menyatakan ditinjau dari hasil pelatihan yang mereka peroleh pelaksanaan pelatihan SAI yang pernah mereka ikuti berkualitas baik, namun masih terdapat $(31,4 \%)$ yang menyatakan bahwa hasil pelatihan SAI yang mereka peroleh kualitasnya cukup dan kurang. Pegawai dengan masa kerja di atas lima tahun dengan jumlah cukup besar $(79,8 \%)$ menyatakan ditinjau dari hasil pelatihan yang mereka peroleh pelaksanaan pelatihan SAI yang pernah mereka ikuti berkualitas baik, hanya sebagian kecil $(20,2 \%)$ responden yang menyatakan bahwa hasil pelatihan SAI yang mereka peroleh cukup dan kurang.

Pegawai Dinas Pendidikan yang pernah mengikuti pelatihan SAI sebanyak 45 orang secara keseluruhan sebanyak $75,5 \%$ menyatakan bahwa hasil pelatihan yang mereka peroleh baik dan hanya $24,5 \%$ yang menyatakan cukup dan kurang. Penguasaan pengetahuan yang merupakan hasil dari pelaksanaan pelatihan baik menurut tanggapan pegawai hal ini dinyatakan bahwa mereka memperoleh peningkatan pengetahuan dan pengetahuan tersebut mendukung aplikasi dalam kerja.

Responden pegawai yang mengikuti pelatihan SAI juga menyatakan memperoleh peningkatan keterampilan dan keterampilan tersebut bermanfaat dalam penyelesaian tugas setelah mengikuti pelatihan. Pegawai yang telah mengikuti pelatihan SAI juga menyatakan hasil dari pelaksanaan pelatihan dalam bentuk perubahan sikap mereka peningkatan ketelitian 
dan disiplin dalam kerja kurang dirasakan. Hasil ini menunjukkan bahwa hasil pelatihan SAI yang diperoleh pegawai cukup baik namun perlu ditingkatkan dalam hal tujuan untuk merubah sikap agar semakin teliti dan disiplin dalam bertugas hingga memungkinkan hasil pelatihan maksimal.

\section{Kelemahan model pelatihan selama ini}

Komponen keterkaitan analisis kebutuhan pelatihan, penyusunan, pelaksanaan program, dengan evaluasi dan keterkaitan kebijakan, dan materi pelatihan dengan kebutuhan kerja merupakan dua komponen kelemahan model pelatihan yang telah dilakukan. Model pelatihan yang telah dilakukan memiliki kelemahan bila lemahnya keterkaitan analisis kebutuhan pelatihan, penyusunan, pelaksanaan program, dan evaluasi diindikasikan dengan kebutuhan pelatihan dengan penyusunan dan pelaksanaan program dan penyusunan, pelaksanaan dengan evaluasi untuk tindak lanjut tidak berkaitan. Model pelatihan yang telah dilakukan juga memiliki kelemahan bila lemahnya keterkaitan kebijakan pimpinan, materi pelatihan, dengan kebutuhan kerja yang diindikasikan kebijakan institusi terlepas dari materi pelatihan yang diperoleh/ diberikan dan materi pelatihan tidak berhubungan dengan kebutuhan kerja.

Persentase tanggapan responden terhadap pelatihan terkait dengan kelemahan model pelatihan SAl yang pernah diikuti seperti pada Gambar 2. Pegawai dengan masa kerja di bawah lima tahun sebanyak $44,1 \%$ menyatakan model pelatihan SAI yang pernah mereka ikuti berkualitas baik, namun masih terdapat sejumlah besar peserta pelatihan sebanyak 55,9\% yang menyatakan bahwa model pelatihan SAI yang mereka ikuti cukup dan kurang. Pegawai dengan masa kerja di atas lima tahun sebagian $(55,4 \%)$ menyatakan ditinjau dari model pelatihan yang mereka ikuti, model pelatihan SAI yang pernah mereka ikuti berkualitas baik, hanya sebagian lainnya $(44,6 \%)$ respponden yang menyatakan bahwa model pelatihan SAl yang pernah mereka ikuti cukup dan kurang. Pegawai Dinas Pendidikan yang pernah mengikuti pelatihan SAI sebanyak 45 orang secara keseluruhan sebanyak $51,1 \%$ menyatakan bahwa model pelatihan yang mereka ikuti berkualitas baik dan $48,9 \%$ yang menyatakan cukup dan kurang.

Model pelatihan yang pernah diikuti oleh pegawai memiliki beberapa kelemahan. Menurut mereka model pelatihan yang telah dikuti kurang memiliki keterkaitan analisis kebutuhan pelatihan, penyusunan, pelaksanaan program, dengan evaluasi karena mereka tidak pernah ditanya tentang materi yang perlu diberikan. Hal ini mengindikasikan bahwa kebutuhan pelatihan dengan penyusunan dan pelaksanaan program dan penyusunan, pelaksanaan dengan evaluasi untuk tindak lanjut tidak berkaitan. Model pelatihan yang telah diikuti pegawai juga memiliki kelemahan bila dikaitkan dengan kebijakan pimpinan, materi pelatihan, dengan kebutuhan kerja. Kebijakan institusi kerja tempat pegawai bertugas tidak pernah dilibatkan dalam penentuan materi pelatihan yang diberikan, sehingga materi pelatihan tidak berhubungan dengan kebutuhan kerja.

\section{HASIL PENELITIAN}

Hasil survey menunjukkan bahwa model pelatihan SAI yang diterapkan pada pelatihan pegawai masih belum sesuai dengan harapan peserta pelatihan. Peningkatan kualitas model pelatihan SAI dimaksud masih perlu perbaikan. Perbaikan model pelatihan dapat dilakukan dalam aspek keterkaitan analisis kebutuhan pelaksanaan program, dan evaluasi; serta keterkaitan kebijakan, materi pelatihan, dan kebutuhan kerja. Pelatihan yang pernah diikuti pegawai dilakukan berjenjang sesuai dengan jabatan dan kurang terkait dengan promosi jabatan maupun gaji. Pelatihan yang tidak terkait dengan promosi jabatan atau tujuan tertentu yang berkaitan dengan jabatan pegawai sangat berakibat pada motivasi pegawai dalam mengikuti pelatihan. Motivasi yang dapat berperan pada semangat belajar dan upaya kuat untuk mencapai hasil pelatihan yang maksimal. Manajemen pelatihan yang direncanakan terlaksana dengan baik dan pelaksanaan pelatihan dievaluasi atau ditindaklanjuti dengan baik saat setelah pelatihan di lembaga pelatihan namun evaluasi ini tidak dilakukan saat melaksanakan tugas. Meskipun manajemen pelatihan terlaksana dengan baik, evaluasi yang kurang menyeluruh atau tidak mengukur keadaan sebenarnya dari peserta pelatihan berakibat kesalahan dalam memperoleh data informasi kemampuan peserta pelatihan. Umpan balik yang dilakukan berdasarkan hasil pelatihan yang kurang menyeluruh akan melenceng dari sasaran. Umpan balik yang dilakukan berdasarkan data hasil pelatihan yang tidak tepat tidak dapat memperbaiki proses pelatihan itu sendiri. Hal ini menunjukkan bahwa evaluasi saat pelatihan, setelah pelatihan, dan saat melaksanakan tugas yang berkaitan dengan materi pelatihan penting untuk dilakukan agar umpan balik program pelatihan dapat memperbaiki pelaksanaan pelatihan.

Penggunaan metode penyajian materi pelatihan 
kurang sesuai dengan materi pelatihan sehingga metode tersebut tidak mendukung penguasaan materi pelatihan. Metode yang digunakan pelatih atau pelatih cenderung pada metode konvensional. Metode ini menekankan penyajian materi ceramah dan dilanjutkan tanya jawab disertai pemberian kegiatan praktik yang minim. Metode yang semestinya tepat untuk digunakan menurut responden adalah studi kasus yang dapat menghadapkan pegawai pada permasalahan yang sebenarnya dihadapi dan mencari solusi masalah tersebut. Kasus yang digunakan sebagai sumber belajar tentu sangat seragam untuk berbagai peseta pelatihan yang berasal dari berbagai daerah. Metode kasus yang digunakan tanpa meninjau permasalahan aktual ditempat peserta pelatihan bertugas dapat mengakibatkan peserta kurang termotivasi, sehingga penguasaan materi pelatihan belum maksimal.

Penggunaan media oleh pelatih saat menyajikan materi pelatihan umumnya dapat memperjelas penyajian materi pelatihan. Penyajian materi teori dalam pelatihan oleh pelatih menambah pengetahuan, terkait dan mendukung kegiatan praktik, namun praktik yang dilakukan kurang meningkatkan keterampilan serta sikap pegawai. Penguasaan pengetahuan dan keterampilan melalui praktik penting untuk diperoleh peserta pelatihan, namun perbaikan sikap juga harus menjadi perhatian dalam perencanaan pelatihan. Peningkatan pengetahuan dan keterampilan bermanfaat dalam penyelesaian tugas setelah mengikuti pelatihan. Pegawai yang telah mengikuti pelatihan SAI juga menyatakan hasil dari pelaksanaan pelatihan dalam bentuk perubahan sikap mereka dalam peningkatan ketelitian dan disiplin dalam kerja kurang dirasakan. Pengetahuan dan keterampilan kurang bermanfaat bila pegawai kurang teliti atau mengabaikan disiplin. Ketelitian yang minim dapat menyebabkan berbagai kekeliruan dalam mengerjakan tugas sehari-hari pegawai. Pengabaian disiplin kerja menyebabkan pekerjaan yang harus dilaksankan menjadi terbengkalai. Model pelatihan yang memberikan kasuskasus praktis yang sederhana hingga kompleks dengan jumlah permasalahan yang banyak dapat digunakan untuk melatih ketelitian pegawai.

Model pelatihan yang telah dikuti pegawai kurang memiliki keterkaitan analisis kebutuhan pelatihan, penyusunan, pelaksanaan program, dengan evaluasi karena mereka tidak pernah ditanya tentang materi yang perlu diberikan. Keterlibatan peserta pelatihan dalam memilih materi, metode, dan cara evaluasi penting untuk dilakukan agar terjadi saling keterkaitan antara analisis kebutuhan pelatihan, penyusunan, pelaksanaan program, dengan evaluasi. Evaluasi yang dilakukan pada pelatihan sebelumnya hanya terfokus pada evaluasi hasil pelatihan dalam penguasaan teori dan keterampilan praktik. Evaluasi ini perlu diperbaiki dengan menerapkan evaluasi proses, hasil, maupun setelah pelatihan yaitu saat bertugas. Evaluasi hasil mengukur pemahaman teori, kemampuan praktis, maupun sikap pegawai. Evaluasi proses dilakukan saat pelatihan pegawai berlangsung pada tahap perencanaan, pelaksanaan, maupun akhir pelatihan.

Pelatihan pegawai dalam pelaksanaan SAI yang dilangsungkan saat ini bagi pegawai berjenjang sesuai dengan jabatan dan kurang terkait dengan promosi jabatan maupun perbaikan gaji. Hal ini merupakan salah satu kelemahan model pelatihan konvensional. Pelatihan bagi pegawai hendaknya dikaitkan dengan promosi jabatan atau perbaikan insentif atau pendapatan bagi pegawai. Penelitian menunjukkan bahwa pelatihan formal di tempat kerja (FOJT) dapat berdampak positif pada penghasilan dan kesempatan promosi jabatan (Evertsson, 2004:79). Pelatihan ditempat kerja yang berjenjang dan terkait dengan pendapatan pegawai penting untuk dilakukan. Pengaitan ini diupayakan agar pegawai sebagai peserta pelatihan termotivasi untuk mengikuti pelatihan dan memperoleh manfaat yang maksimal dari kegiatan pelatihan. Pelatihan dimaksud dapat berperan setara dengan pendidikan tinggi menurut hasil studi bahwa pelatihan di tempat kerja setara dengan pendidikan tinggi dalam hal mengurangi resiko pekerja berpendapatan rendah (Cuesta \& Salverda, 2009: 5).

Manajemen pelatihan SAI bagi pegawai saat ini yang direncanakan terlaksana dengan baik dan pelaksanaan pelatihan dievaluasi atau ditindak lanjuti dengan baik saat setelah pelatihan di lembaga pelatihan namun evaluasi ini tidak dilakukan saat melaksanakan tugas. Sistem dan manajemen pelatihan pegawai dalam pelaksanaan SAI membutuhkan perbaikan. Hasil evaluasi sangat dibutuhkan dalam pelatihan di tempat kerja maupun pelatihan konvensional untuk di gunakan sebagai tindak lanjut pelatihan saat setelah pelatihan hingga di lembaga asal peserta pelatihan. Lembaga pengembangan profesional modern memandang sangat penting hasil evaluasi peserta pelatihan setelah peserta kembali bekerja di lembaga asal meskipun dengan menggunakan perangkat teknologi internet secara online. Upaya ini dilakukan untuk meminimalkan kelemahan evaluasi model pelatihan konvensional di lembaga pelatihan. Evaluasi pelatihan yang telah dilakukan secara on-line dapat mengungkap kinerja, hasil pelatihan, dan hubungan antarpribadi yang lebih baik dibanding dan pelatihan konvensional dengan tatap muka langsung. Hasil evaluasi dan teknik evaluasi 
peserta pelatihan tepat diterapkan untuk perbaikan pelatihan pegawai (Spotts \& Chelte, 2005: 127).

Evaluasi hasil pelatihan saat pegawai bertugas di lembaganya masing-masing bersinggungan dengan evaluasi kinerja. Evaluasi hasil pelatihan dapat berperan sebagai pengukuran kinerja yang berkaitan dengan beberapa faktor. Hasil penelitian menunjukkan bahwa komitmen manajemen, pelatihan, serta budaya organisasi terbukti berpengaruh secara positif terhadap pengembangan sistem pengukuran kinerja, akuntabilitas kinerja, dan penggunaan informasi kinerja. Otoritas pengambilan keputusan terbukti berpengaruh positif terhadap pengembangan sistem pengukuran kinerja, namun tidak berpengaruh terhadap akuntabilitas kinerja dan penggunaan informasi kinerja. Hal ini menunjukkan bahwa instansi pemerintah harus dapat mengembangkan sistem pengukuran kinerja secara komprehensif dan terintegrasi ke dalam manajemen pengambilan keputusan, dengan memperhatikan berbagai faktor yang berpengaruh terhadap sukses atau gagalnya implementasi sistem pengukuran tersebut. Implementasi sistem pengukuran kinerja yang dapat meningkatkan kinerja pegawai pemerintah mensyaratkan pemerintah harus menjalankan mekanisme insentif program secara proporsional, meningkatkan kualitas sistem informasi dan memberikan pelatihan sesuai dengan kebutuhan (Nurkhamid, 2008: 68).

\section{KESIMPULAN}

Kesimpulan yang dapat ditarik berdasarkan analisis data hasil survey dan pembahasan yaitu pelatihan pegawai dalam pelaksanaan SAI yang dilangsungkan saat ini berjenjang sesuai dengan jabatan dan kurang terkait dengan promosi jabatan mapun gaji. Manajemen pelatihan yang direncanakan terlaksana dengan baik dan pelaksanaan pelatihan dievaluasi atau ditindak lanjuti dengan baik saat setelah pelatihan di lembaga pelatihan namun evaluasi ini tidak dilakukan saat melaksanakan tugas. Perencanaan dan pelaksanaan model pelatihan alternatif sangat dibutuhkan oleh pegawai sebagai upaya peningkatan pengetahuan, keterampilan, dan sikap pegawai dalam pelaksanaan SAI. Model pelatihan di tempat kerja hendaknya dikembangkan dan digunakan sebagai salah satu alternatif upaya peningkatan pengetahuan, keterampilan, dan sikap pegawai dalam pelaksanaan SAI.

\section{DAFTAR PUSTAKA}

Badan Pemeriksa Keuangan RI. (2006). Hasil pemeriksaan semester I Tahun 2006 atas laporan keuangan provinsi Kepulauan Riau tahun anggaran 2005 di Tanjungpinang. Jakarta: BPK.

Badan Pemeriksa Keuangan RI. (2008). Laporan atas laporan keuangan pemerintah Provinsi Kepulauan Riau tahun anggaran 2007. Batam: Auditorat Utama Keuangan Negara V Perwakilan BPK RI di Batam.

Cuesta, B. M \& Salverda, W. (2009). Low-wage employment and the role of education and onthe-job training. Labour 23.

Evertsson, M. (2004). Formal on-the-job training: $A$ gender-typed experience and wage-related advantages? European Sociological Review. Vol 20(1).

Nurkhamid, S. (2008). Implementasi inovasi sistem pengukuran kinerja instansi pemerintah. Jurnal Akuntansi Pemerintah. Vol.3 (1).

Schuler, R. S. (1987). Personal and human resources management (third ed.). New York: West Publishing Company.

Spotts, E. H \& Chelte, F. A. (2005). Evaluating the effects of team composition and performance environment on team performance. Journal of Behavioral and Applied Management. Vol 6(2). 